\title{
Perception of Students about Violence in Process Teaching- Learning in University Education
}

\author{
PhD Flor Ivett Reyes Guillén ${ }^{1 *}$, Socorro Fonseca Córdoba ${ }^{1}$, Leticia del Carmen Flores Alfaro ${ }^{1}$, \\ Luis Enrique Nájera Ortiz ${ }^{2}$, Gabriel Solís Gutman', Fidel Torres Rojas ${ }^{1}$, Miguel Ángel Gómez \\ López $^{1}$ \\ ${ }^{1}$ Autonomous University of Chiapas, Mexico \\ ${ }^{2}$ College of Bachelors of Chiapas, Mexico
}

*Corresponding Author: Flor Ivett Reyes Guillén PhD Autonomous University of Chiapas, Mexico

\begin{abstract}
The main objective of this study was to analyses the perceptions of university students regarding violence in the teaching-learning process. It was a study between vocational training in Law versus vocational training in the Social Sciences. The main findings indicate a clear difference between the two areas of vocational training. The students of the Social Sciences perceive, in large percentage, the quality in the development of their professional training. Contrary, in the degree in law, students perceive that the presentation of contents of the program that the student will attend is being neglected, being understood to this act like the door to the search of the attention and motivation of the student before the new Knowledge that will come to him during the course development. This can be understood given the high use of memorization as the main working tool in Law; but the lack of motivation and techniques that allow a process of memorization together with the analysis and comprehension is what makes the success difficult.
\end{abstract}

Keywords: Perception, Violence, Process Teaching-Learning, University Education

\section{INTRODUCTION}

At present and having as a context a globalized world and with complexities that result from this changing process (Guiddens, 2005), within the higher education one has as main objective to form professionals in an integral way, with excellence Academically and to perform competently within a theoretical and humanitarian framework, including strengthening their capacity for self-criticism and continuous updating of their knowledge (Barnett, 2001). In other words, the university has a social commitment to train professionals who can adapt and produce in a real and changing world.

From The local to the global level, there is a panorama with serious security problems, social violence and loss of values that allow a peaceful society (Concha-Eastman, 2004). In this context, universities have the challenge of forming citizens committed to the public welfare and progress of all social sectors in a way that will strengthen security and reduce violence in all its expressions, areas and actors' social networks that generate it.

However, universities reflect the social environment while they are the benchmark in the search for solutions to social problems (Bornand, 2011). It Is therefore important to address the issue of violence in institutions of higher education and the perception that students have. The social climate that develops in the universities greatly influences the school's performance and ensures the training of the professional; This also predetermines the replication of behaviors towards their later professional work.

In this article, the results presented relate specifically to the perception they have, university students, about the forms of violence teachers exercise about their students in terms of the teaching they receive from disciplines such as Law, History, Social Anthropology, Sociology and Economics. The context in which the study is located has as relevant characteristics its location, Zona Altos Tseltal-Tsotsil of Chiapas, México, area with high registration of students of indigenous origin and with native language other than Spanish. Also, area with specific characteristics of great socio-economic backwardness.

The study was carried out at the Autonomous University of Chiapas, specifically in the Faculties of Law and Social Sciences, during the period from November 2017 to September 2018. 


\section{RESEARCH METHOD}

a) FIRST PHASE. The research was transversal and comparative, which raised the analysis of the structure and interactoral relations that keep the processes of violence in higher education institutions.

The study, cross-curricular by Faculty in which they are inserted, was carried out by means of a stratified random sampling, including equality of proportions by strata. Within the strata covered are those related to the degrees they take, in this case stratum Bachelors in the Social Sciences and Degree in Law. Participants were selected under informed consent considering the ethical principles of rigor for human population studies.

The Information gathering tool, questionnaire, allowed us to identify the social characteristics of the actors involved in the teaching-learning process. Descriptive statistical analysis was carried out for the variables measured through the survey.

b) SECOND PHASE. Systematization and registration. It consisted in generating intervention strategies as proposals for the prevention and treatment of violence in the teaching-learning process.

\section{RESULTS}

Of a sample $n=200,50 \%$ correspond to young people who take the degree in Law and in terms of tuition represents the highest proportion of students between both faculties. The following percentage (37.5\%) It is that of the students of Economy, whose tuition is the highest one within the Faculty of Social Sciences where it is inserted. Followed by a degree in Sociology (15\%) And in equality of proportions the degrees in History and Social Anthropology (5\%).

As for the average age of the sample in total $(n=200)$ is 20 years. These Faculties are in the city of San Cristóbal de Las Casas, Chiapas, Mexico, area of high cultural and ethnic diversity. Within the sample raised in the Faculty of Social Sciences, 28\% is represented by students with native mother tongue (Tzeltal, Tzotzil, Zoque and Zapotec). For the Faculty of Law these students with indigenous native language are represented by only $5 \%$ of the total sample (Tzotzil and Tzeltal).

In the variables related to the identification of violence in the teaching-learning process we must be marked the difference between the two faculties, Faculty of Social Sciences (FCS) and Faculty of Law (FD):

\subsection{Identification of Violence in the Teaching-Learning Process Perceived by University-Level Students}

- Presentation of the course content: FCS (59\%); FD (21\%)

- Contribution of the teacher for the group to develop an appropriate learning environment: FCS (59\%); FD (26\%)

- Prompt and timely Feedback of progress through assessment, follow-up and correction: FCS (30\%); FD (11\%)

- Program Advance: $100 \%$ in both faculties

- Quality with which the topics in the courses were reviewed: FCS (52\% very good to excellent); FD (25\% very good to excellent).

- Teachers 'contribution to understanding, assimilation or developing the different subjects of the training discipline:

FCS: Interest 52\%

Discussion Capacity 19\%

Fellowship $16 \%$

Teamwork 9\%

Individual Growth 4\% 
FD: Interest $35 \%$

Discussion Capacity 25\%

Fellowship 25\%

Teamwork $11 \%$

Individual Growth 4\%

- Motivation on the part of teachers so that their students develop or improve their vocational training: FCS (43\%); FD (11\%)

- For reflection on the value of respect: FCS (42\%); FD (14\%)

- For reflection on tolerance: FCS (30\%); FD (43\%)

- For reflection on responsibility: FCS (46\%); FD (17\%)

- For reflection on the spirit of service: FCS (22\%); FD (12\%)

- For reflection on social commitment: FCS (34\%); FD (16\%)

- For reflection on professional ethics: FCS (38\%); FD (24\%)

\subsection{Mastery of the Training Area by the Student}

- Mastery of the subjects already reviewed in the course of their vocational training: FCS (38\%); FD $(41 \%)$

- The attitudes of the group in general:

FCS: Responsibility to study and deliver the entrusted activities $63 \%$

Apathy $8 \%$

Punctuality $9 \%$

Low Academic Level 2\%

Participation $14 \%$

Demotivation $4 \%$

FD: Responsibility to study and deliver the entrusted activities $33 \%$

Apathy $38 \%$

Punctuality $5 \%$

Low Academic Level 4\%

Participation $15 \%$

Demotivation 5\%

Regarding the indicators that measure the actions of teachers in the process of training students, specifically within the teaching-learning process, the School of Social Sciences obtains $76.47 \%$ of compliance with these. The remaining percentage has alarm points as to the number of teachers who tend to move away from good practice.

With regard to the Law School, the situation is complicated as the inverse happens, since the perception of the students, only $17.64 \%$ of the indicators are positively met by a high percentage of their teachers, while the remaining number It corresponds to indicators in alarm situation as they manifest the bad practices within their teaching processes at a higher level. It Is also of interest to rescue that most of the indicators are presented on alert for the Degree in Law.

Finally, students from both faculties (FCS, 75\% and FD, 82\%) They perceive the following actions as representative of violence within their professional training process:

- Lack of knowledge of some teachers 
- Absenteeism on the part of teachers

- Don't give us time for breakfast or lunch

- Internal problems between teachers and generate stress environment

- Teachers humiliate students

- Violence reflected in retaliation ratings

- Corruption and racism

- Problems between teachers and students

\section{ANALYSIS AND CONClusions}

The processes of exploration and evaluation of those that have been the subject of the university training programs, have shown that it is not enough to know their quantitative results to warn the causes of their problems such as the low use of school, desertion, the differences in learning among students, and even less to understand the various ways in which they assume their relationship with knowledge or their attitudes to the process of teaching-learning.

Therefore, it has been of interest in the educational and interdisciplinary research, to find the elements of subjective type that complement this panorama. In other words, there is a need to attend to psychological and social processes, as well as contextual factors that affect educational practice, to help us understand the results of vocational training.

This need is not only seen through the exploration of what teachers perceive, but also from the exploration of what the users of the educational system perceive the students. However, most of the studies have focused more on the teacher as the main mediator between the formal specifications of a curriculum and what really happens in the classrooms.

The present study is issuing students' perception of the teaching-learning process in which they are immersed, and which correspond to the product with or without quality.

According to Coll and Miras (1993), the student's constructions are also a mediating element and perhaps the most interesting among the educational influence that the teacher exerts, the contents or school objects, and the results in the learning. In other words, the representations that are given within the educational act by professors and students take importance, since they are formulated and characterized by a specific logic and language.

In the law degree is neglecting the presentation of contents of the program that the student will attend, understanding this act as the door to the search for the attention and motivation of the student to the new knowledge that will come to him during the course development. In the degrees inserted in the social sciences most of the teachers do take care of this first approach towards their students and it favors even the care in the quality of what is developing in the sequence of the course. The latter can be seen clearly as the rest of the indicators are largely outnumbered.

Reviewing by paragraphs, in relation to the development of contents we have for the degrees inserted in the social sciences, not thus for right, which are achieved favorably:

- The teacher's contribution for the group to develop an appropriate learning environment.

- Prompt and timely feedback of progress through evaluation, follow-up and correction.

- The quality with which topics were addressed in the courses.

- The contribution of teachers to the comprehension, assimilation or development of the different subjects of the training discipline.

However, it leaves us on the alert that the degree of progress in terms of the information contained in the program in the course of the development of the curriculum is achieved only in the range of 70$90 \%$ of its totality.

Respect to the work of motivation and projection of values such as respect, tolerance, responsibility, spirit of service, social commitment and professional ethics, the degrees of the Social Sciences are 
widely qualified within the teaching. Paradoxically, within the law degree students consider not having these formative and psychological processes that integrate their professional training, claiming that less than half of their teachers have these actions within their teaching activities. This can be understood given the high use of memorization as the main working tool in Law; but the lack of motivation and techniques that allow a process of memorization together with the analysis and comprehension is what makes the success difficult.

In the indicators of the domain of the area of training by the student, it is of importance to mention that the students perceive as main obstacle for the proper achievement of their process of formation to the timetables and the mastery of the subject by the teachers.

Finally, as unanimous expression among university students are recognized as violent actions received in their training process to the following:

- Lack of knowledge of some teachers

- Absenteeism on the part of teachers

- Humiliation of teachers towards students

- Violence reflected in retaliation ratings

- Corruption and racism

- Problems between teachers and students

- Do not give us time for breakfast or lunch

This last expression, even when it has standardized the time rigor in the higher educational level, does not make it a non-violent act, this action represents a direct aggression to the physical health of the students.

This gives us the opportunity to propose changes or alternatives in the organization of teaching, and in general on the role and performance of teachers that facilitate students, not only the construction of knowledge, but also their social development and affective.

From the findings found in the exposed research we can understand the representations of university students about the performance of the teachers and their relationship with them influencing the way they perceive their own learning.

It Is important to mention, trying to explain this reality, that most of the higher level teachers were not trained in the field of teaching, that is, they do not have a pedagogical training and rarely with skills in this sense that allow to show not only their skills as a professional within the discipline in which they teach, but also in the best techniques for the development of their teaching activities.

\subsection{Mechanisms to Overcome this Condition}

In educational spaces, the teacher must consider as a necessity his training in the field of the teaching and the recognition of the relations between both from the integration of the theory of the learning, in the theory and practice of the teaching (Reyes, 2002).

The pedagogical and psychological conceptions about the learning process are an important element in establishing the relationships within the teaching process, and at the university level it is necessary to have a training held on theoretical knowledge that enriches the interdisciplinary process (Cabezas, 2008), such as:

- Cognitive Psychology

- General Psychology

- Psychology of the Education, among others.

As an important part to consider is that Psychology is crucial within the educational process. This discipline oversees the study of the behavior in the formative process of the person.

In the psychology of education, or educational psychology, the processes of teaching and learning are addressed; It extends the methods and theories of the psychology in general and bases its own theories 
within the educational field (Marqués, 2000; Torre, 2001). This is the importance of university-level teachers supporting this discipline to improve the relationships and behaviors that are developed in the classroom in the teaching-learning process.

There are several elements that provide lights of how to prevent violent acts, by condition of gender, race, socioeconomic level, condition of health (Hüfner and Schlaak, 2005). It is also true that, in a concrete way we can list the elements that They would promote an environment of peace and reciprocity in the teaching-learning process at the university level, where the main objective is the training of professionals with integral vision and successfully in their work insertion.

The authors of this document propose to consider the following elements focused on the teachinglearning process, for harmonization and success in the process of training young university students:

- Citizen Training. Within Society, the school is a primary space for socialization and is fundamental to the formation of citizenship. For These times the school has become a space with more flexible channels of participation and communication that promote new teaching models.

- Recognition and respect of rights. The School holds a broad responsibility when training people to achieve respect and respect for their rights.

- Form and care for integrity. In specific at the university level the responsibility increases due to the need of labor insertion when completing its formative process and it is in this successful insertion where we must focus the interest for the integral formation of the future professional.

\section{REFERENCES}

[1] Guiddens, A. (2005). Un mundo desbocado. Los efectos de la globalización en nuestras vidas.

[2] Barnett, Ronald (2001). Los límites de la competencia. El conocimiento, la educación superior y la sociedad. Barcelona, Gedisa

[3] Concha-Eastman, A. (2004). Violencia urbana en América Latina y el Caribe: dimensiones, explicaciones, acciones. En Rotker S. (eds.), Ciudadanías del miedo, Caracas: Rutgers, 2004.

[4] Bornand AM. (2011). Escuela y subjetividad política. Una indagación sobre los significados que los estudiantes construyen en torno a su formación política en la institución escolar. Santiago: Universidad de Chile. Facultad de Ciencias Sociales. Departamento de Educación.

[5] Coll, César y Mariana Miras. "La representación mutua profesor/ alumno y sus repercusiones sobre la enseñanza y el aprendizaje", en César Coll, Jesús Palacios y Álvaro Marchesi (comps.). Desarrollo Psicológico y educación II. Psicología de la Educación, Madrid, Alianza, 1993.

[6] Reyes, L. y otros. (2002): "Contradicción dialéctica entre dependencia e independencia cognoscitiva de los estudiantes”. En: Revista Pedagogía Universitaria, vol. 7, n. ${ }^{\circ}$ 4, pp. 61-67, La Habana.

[7] Cabezas, C. (2008). El acoso del profesor hacia el alumno. Madrid: CERSA

[8] Marqués, Pere (2000). Los medios didácticos: componentes, tipología, funciones, ventajas, evaluación.

[9] Torre, R. (2001). Comunidad de aprendizaje: la educación en función del desarrollo local y el aprendizaje. Simposio Internacional sobre Comunidades de Aprendizaje, Barcelona Forum 2004, Barcelona

[10] Hüfner K y C Schlaak. (2005). Violación de los Derechos Humanos en la Práctica. Asociación Alemana para las Naciones Unidas y la Comisión Alemana para la UNESCO. https:// www.unesco.de/ fileadmin/medien/Dokumente/Wissenschaft/DerechosHumanos_quepuedohacer.pdf

\section{AUTHORS' BIOGRAPHY}

Flor Ivett Reyes Guillén PhD in Sciences, Natural Resources and Sustainable Development from El Colegio de la Frontera Sur. Professor -Researcher of the Faculty of Social Sciences of the Autonomous University of Chiapas, Mexico. President of the Research Network in Public Health and Care for Development Problems, REINVESAD. Member of the academic corps, society, culture and education Research line: Cognitive analysis for the interpretation of social processes and development. Society, Sustainability and Health. Calle presidente obregón s/n Fracc. Revolución Mexicana.

Socorro Fonseca Córdoba $\mathrm{PhD}$ in education from the Institute of University Studies. ProfessorResearcher at the Faculty of Social Sciences, Campus III, UNACH. Member of the academic corps, society, culture and education. Calle presidente obregón s/n Fracc. Revolución Mexicana.

Leticia del Carmen Flores Alfaro, $\mathrm{PhD}$ in public Health Sciences by the Institute of Sciences and Arts of Chiapas. Professor-Researcher at the Faculty of Medicine of the UNACH. Member of the 
Academic Corps Society, culture and education. Belisario Domínguez Kilómetro 1081, Colina Universitaria, 29050 Tuxtla Gutiérrez, Chis.

Luis Enrique Nájera Ortiz, PhD in social and humanistic sciences. Professor of College of Bachelors of Chiapas. LGAC: Educational policies, public policies for adolescent population and educational orientation and mentoring. Facilitator of courses-workshops related to human development and accompaniment in didactic strategies. COBACH 58 Periférico Nte. Ote. s/n.

Gabriel Solís Gutman, Master's in social and Humanistic Sciences by the Center for Higher Studies on Mexico and Central America, CESMECA, UNICAH. Professor -Researcher of the Faculty of Social Sciences of the Autonomous University of Chiapas, Mexico. Calle presidente obregón s/n Fracc. Revolución Mexicana.

Fidel Torres Rojas, PHD in Pedagogy by the Institute of Higher Studies "Emilio Estebanell". Teacher in Education by the Faculty of Humanities of the UNACH. Professor -Researcher of the Faculty of Social Sciences of the Autonomous University of Chiapas, Mexico. Calle presidente obregón s/n Fracc. Revolución Mexicana.

Miguel Ángel Gómez López, Master's in Economy and Busyness by the Altos de Chiapas University. Professor -Researcher of the Faculty of Social Sciences of the Autonomous University of Chiapas, Mexico. Calle presidente obregón s/n Fracc. Revolución Mexicana.

Citation: Flor Ivett Reyes Guillén, et.al. "Perception of Students about Violence in Process TeachingLearning in University Education" International Journal of Research in Sociology and Anthropology (IJRSA), vol 5, no. 2, 2019, pp. 44-50. doi:http://dx.doi.org/ 10.20431/2454-8677.0502006.

Copyright: (C) 2019 Authors. This is an open-access article distributed under the terms of the Creative Commons Attribution License, which permits unrestricted use, distribution, and reproduction in any medium, provided the original author and source are credited. 